\title{
MODELIRANJE NARAVNIH PROCESOV NA PRIMERU ZEMELJSKIH PLAZOV
}

\author{
Blaž Komac*, Matija Zorn** \\ Geografski inštitut Antona Melika ZRC SAZU, Gosposka ulica I3, \\ SI-I000 Ljubljana, Slovenija \\ *e-mail: blaz.komac@zrc-sazu.si, \\ **matija.zorn@zrc-sazu.si
}

Izvirni znanstveni članek

COBISS 1.01

\section{Izvleček}

Na primeru Goriških brd predstavljamo deterministično in probabilistično metodo za izdelavo zemljevidov plazovitosti oziroma procesnih geomorfoloških zemljevidov za zemeljske plazove. Deterministični zemljevid plazovitosti smo izdelali z metodo ponderiranja, za probabilistični zemljevid pa smo uporabili Dempster-Shaferjev algoritem. Deterministične metode so enostavnejše in hitrejše za izdelavo, vendar tudi manj natančne od probabilističnih. $\mathrm{V}$ članku je predstavljena primerjava obeh metod.

Ključne besede: geografija, geomorfologija, zemljevidi ogroženosti, deterministične metode, probabilistične metode, Dempster-Shaferjev algoritem, Slovenija

\section{MODELLING OF NATURAL PROCESSES ON THE EXAMPLE OF LANDSLIDES}

\begin{abstract}
We present the deterministic and probabilistic modelling of landslide hazard on the example of flysch Goriška brda hills, Western Slovenia. A weighing method was used for the deterministic landslide hazard map elaboration, and the Dempster-Shafer algorithm was used for the probabilistic landslide hazard map elaboration. The deterministic method is more simple and its use is quicker but also less accurate than the probabilistic one. The comparison of the methods are presented in the article.
\end{abstract}

Key words: geography, geomorphology, hazard maps, deterministic methods, probabilistic methods, Dempster-Shafer algorithm, Slovenia 


\section{UVOD}

Na primeru Goriških brd predstavljamo rezultate determinističnega in probabilističnega modeliranja plazovitosti oziroma geomorfnih procesov - zemeljskih plazov.

Metode izdelave zemljevidov geomorfnih procesov delimo na neposredne oziroma kvalitativne ali izkustvene (geomorfološko kartiranje) in posredne ali kvantitativne (izdelava zemljevidov plazovitosti s pomočjo geografskih informacijskih sistemov). Posredne metode delimo na deterministične (metoda ponderiranja) in statistične ali verjetnostne, primer je probabilistična metoda (Zorn in Komac 2004).

Prednost determinističnih metod je, da omogočajo izdelavo zemljevidov plazovitosti le s primerjavo posameznih pokrajinskih prvin ne da bi upoštevale pojave, ki so se že zgodili.

Nekatere deterministične metode omogočajo tudi to (van Westen 1994). Če imamo na razpolago podatke o že sproženih plazovih, je bolje uporabiti probabilistične metode. Uporabljena probabilistična metoda je primerna za ugotavljanje plazovitosti in tudi za modeliranje drugih naravnogeografskih ali družbenogeografskih pojavov.

Deterministični zemljevid plazovitosti smo izdelali z uveljavljeno metodo ponderiranja, za probabilistični zemljevid pa smo prvič v Sloveniji uporabili Dempster-Shaferjev algoritem.

Pri izdelavi modelov smo upoštevali naslednje dejavnike, ki vplivajo na plazenje (Zorn in Komac 2002, 11-12; 2004; 2005):

- litološko sestavo,

- naklon površja,

- vodoravno ukrivljenost površja,

- vpad kamninskih skladov,

- indeks moči vodnih tokov,

- indeks namočenosti tal (Linsday 2002),

- maksimalne 24-urne padavine in

- rabo tal.

Izračuni so bili narejeni s programskima paketoma Idrisi 3.2 in TAS 2.0.7 na podlagi digitalnega modela višin $\mathrm{z}$ velikostjo osnovne celice 12,5 krat 12,5 m.

\section{METODA}

\section{I Metoda ponderiranja}

Večina zemljevidov geomorfnih procesov v Sloveniji je bila izdelana po metodi ponderiranja vplivnih dejavnikov, ni pa še bil izdelan zemljevid s probabilistično metodo.

Pri metodi ponderiranja smo za vsakega od vplivnih dejavnikov najprej izdelali zemljevid, ki prikazuje stopnjo nevarnosti. Stopnje nevarnosti smo določili na podlagi lastnih spoznanj in literature. Vrednosti smo nato standardizirali tako, da smo absolutne vrednosti spremenili v relativne. Na ta način smo lahko zemljevide primerjali med seboj (Zorn in Komac 2004). 
Ker pa vpliv različnih dejavnikov na nastanek pobočnih procesov ni enakovreden, smo vsak dejavnik obtežili ali ponderirali. Temeljna zahteva ponderiranja je, da je vsota vseh uteži ali ponderjev enaka 1, določitev teže posameznega ponderja pa je subjektivna. S standardizacijo (deljenje s številom slojev) in ponderiranjem (množenje slojev, ki prikazujejo različne dejavnike, $\mathrm{z}$ deleži, ki jim pripadajo) smo za vsak dejavnik izdelali delni zemljevid. Uporabili smo naslednje vplivne dejavnike: naklon (2/5), kamninska sestava (2/5), vodoravna ukrivljenost površja (1/10) in gozd (1/10). Drugih dejavnikov pri izdelavi determinističnega zemljevida plazovitosti nismo upoštevali, saj niti po literaturi niti po naših izkušnjah ne bi mogli natančno določiti teže ali pomena posameznih dejavnikov.

Delne zemljevide smo nato kombinirali in dobili skupni zemljevid z vrednostmi $0-1$, ki izraža možnost plazenja. Najvišjo vrednost 1 imajo območja, ki so v vseh posameznih slojih uvrščena v najvišjo kategorijo (Perko 1992, 74). Številčni razpon 0-1 smo nato razdelili v trinajst kategorij, in sicer glede na odklon od aritmetične sredine $(0,25$ standardne deviacije). Tako smo v uporabljenih razredih zaobsegli vse pojave. Opisani postopek izdelave zemljevida plazovitosti z deterministično metodo povzema naslednja enačba (Zorn in Komac 2004):

$\kappa=\frac{\sum_{n=1}^{\infty}\left(\frac{X_{n}}{Y_{n}} * p_{n}\right)}{N}$

Legenda:

$\kappa$... zemljevid plazovitega območja, $\quad n$... sloj,

$N$... skupno število slojev, $\quad p$... utež ali ponder,

$X$... zemljevid nevarnosti vplivnega dejavnika,

$Y$... največja vrednost sloja.

\subsection{Probabilistična metoda $z$ uporabo Dempster-Shaferjevega algoritma}

Pri probabilističnem modeliranju smo uporabili Dempster-Shaferjev algoritem (Dempster 1968; Shafer 1990), ki primerja pomen posameznih dejavnikov za plazenje, temelji pa na podatkih o konkretnih zemeljskih plazovih. Program na vse hierarhično možne načine primerja dejavnike ter zanje izračuna, kakšne so njihove vrednosti (količine) na plazovitih območjih. Te privzame kot merilo. Zato lahko za vsak dejavnik ugotovimo mejne vrednosti, pri katerih prihaja do plazenja. Program nazadnje celotno območje preučevanja primerja s prej omenjenim merilom in ugotavlja podobnosti oziroma razlike med posameznimi območji. Program deluje po Dempster-Shaferjevem algoritmu, ki ga opisuje naslednje pravilo:

$\mathrm{m}(\mathrm{Z})=\frac{\sum m_{1}(X) \cdot m_{2}(Y) ; X \cap Y=Z}{1-\sum m_{1}(X) \cdot m_{2}(Y) ; X \cap Y=0}$, pri čemer je $\mathrm{m}(Z)$ temeljna pripisana verjetnost ali vsota podpore za hipotezo $(Z)$. Če je $\sum m_{1}(X) \cdot m_{2}(Y) ; X \cap Y=0$, potem se enačba glasi:

$\mathrm{m}(\mathrm{Z})=\sum m_{1}(X) \cdot m_{2}(Y) ; X \cap Y=0$. 
Končni rezultat je zemljevid, ki prikazuje možnost nastanka zemeljskih plazov z vidika uporabljenih podlag ter ob takšnih razmerah, kot so bile takrat, ko so nastali upoštevani zemeljski plazovi. Kot plazovita območja nazadnje določimo tista, ki so glede na čim večje število upoštevanih dejavnikov kar najbolj podobna območjem, na katerih je prišlo do plazenja. Možnost plazenja prikažemo z indeksom z vrednostmi $0-1$. Vrednost 1 na zemljevidu pomeni, da lahko pride do plazenja na tistem mestu, ko imajo padavine približno petdesetletno povratno dobo, saj so plazovi, ki smo jih uporabili v modelu, nastali ob takšnih padavinah. Tudi vrednosti na tem zemljevidu smo za lažji kartografski prikaz razdelili na 13 kategorij s pomočjo standardnega odklona ( 0,1 vrednosti) od aritmetične sredine.

\subsection{Dobre in slabe strani metod}

Dobri strani deterministične metode sta kratek čas izdelave zemljevida in preprostost postopka, njena največja slabost pa je subjektivnost (Zorn in Komac 2004; Zorn in Komac 2005). Ker smo pri deterministični metodi uporabili manj podatkovnih slojev, je neposredna primerjava metod lahko sporna. S terenskim preverjanjem smo kljub temu prišli do ustreznih rezultatov. Probabilistična metoda se je izkazala kot primernejša od deterministične, ker:

- smo lahko uporabili veliko število podatkov $(\mathrm{N}=800)$ o zemeljskih plazovih, ki so nastali ob znanih okoliščinah,

- nismo ponderirali v modelu upoštevanih prvin pokrajine, s čimer smo kar se da zmanjšali subjektivnost,

- metoda omogoča izračun tudi, če nimamo podatkov o zemeljskih plazovih za celotno območje preučevanja,

- $\quad$ so rezultati oziroma zemljevidi plazovitosti bližji stanju v naravi, kot zemljevidi, izdelani $\mathrm{z}$ deterministično metodo; to je potrdilo terensko delo.

Preglednica 1: Dobre in slabe strani deterministične in probabilistinče metode.

Table 1: Good and bad sides of deterministic and probability method.

\begin{tabular}{|l|c|c|}
\hline & metoda ponderiranja & probabilistična metoda \\
\hline opis dejanskih razmer v naravi & delno & zelo dobro \\
\hline kompleksnost postopka & preprost & zapleten \\
\hline subjektivnost & subjektivna & manj subjektivna \\
\hline prikazuje čas nastanka procesov & neopredeljen & znan* \\
\hline prikazuje neogrožena območja & ne & delno \\
\hline čas izdelave** & najmanj nekaj dni & najmanj nekaj dni \\
\hline prikazuje intenziteto procesov & ne & ne \\
\hline prikazuje vplivno območja procesov & ne & ne \\
\hline
\end{tabular}

* Uporabili smo podatke o padavinah z znano povratno dobo, ki so sprožile zemeljske plazove.

** Ob predpostavki, da so kartografske podlage na razpolago in že pripravljene za uporabo.

Probabilistična metoda ima tudi slabosti:

- zemljevid, ki je izdelan s probabilistično metodo, je le model; z modeli pa lahko le deloma simuliramo naravne procese, 
- zemljevid temelji na le enem (časovnem) nizu podatkov o usadih in zemeljskih plazovih iz preteklosti,

- uporabljeni so manj zanesljivi podatki o zemeljskih plazovih; posredovali jih niso strokovnjaki ampak kmetovalci na predlog občine, ker so bili zaradi višine škode upravičeni do državne pomoči, zato so možna odstopanja.

\section{ZEMELJSKI PLAZOVI V GORIŠKIH BRDIH LETA 1998}

V Goriških brdih so bile jeseni leta 1998 močne padavine s približno petdesetletno povratno dobo. Tako je šestega oktobra $v 24$ urah padlo $175 \mathrm{~mm}$ padavin, $\mathrm{v}$ času od 28. septembra do 13. oktobra pa skupaj $433 \mathrm{~mm}$ padavin, ali povprečno $31 \mathrm{~mm}$ padavin dnevno. Intenzivne padavine so zlasti v flišnih južnih Goriških brdih sprožile prek 800 do nekaj metrov globokih zemeljskih plazov, ki so na $41,32 \mathrm{~km}^{2}$ velikem območju obsegali $1,7 \%$ površine.

\section{I Zemljevid plazovitosti Goriških brd}

Z opisanima metodama smo izdelali zemljevida plazovitosti, ki sta prikazana na naslednjih slikah. Natančnost zemljevidov smo preverili na terenu, s statistično analizo pa smo ugotovili, da so v južnih Goriških brdih zelo plazoviti zlasti vinogradi na severovzhodnih ali jugozahodnih konkavnih pobočjih s povprečnim naklonom $20^{\circ}$, ki so povprečno $70 \mathrm{~m}$ oddaljeni od slemen. Iz prikaza smo izločili ravna območja z naklonom pod $6^{\circ}$, kjer geomorfni procesi po definiciji niso pomembni za oblikovanje površja.

Slika 1: Površina plazovitih območij glede na kategorijo plazovitosti (1-13) oziroma glede na uporabljeno metodo izdelave zemljevida plazovitosti.

Figure 1: Area according to landslide hazard in categories (1-13) and according to the method used.

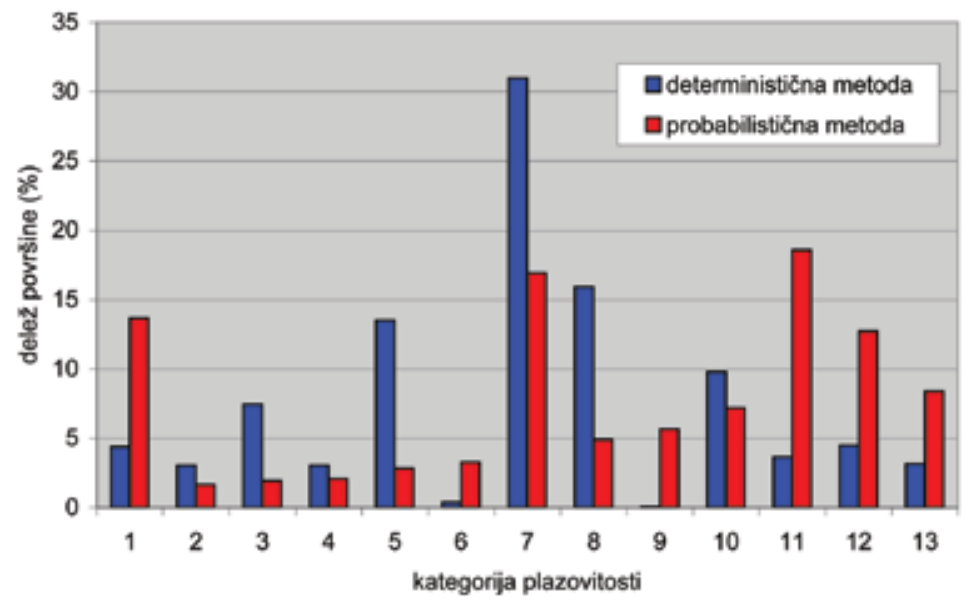


Slika 2: Zemljevid plazovitosti, izdelan z deterministično metodo.

Figure 2: Deterministic landslide hazard map.

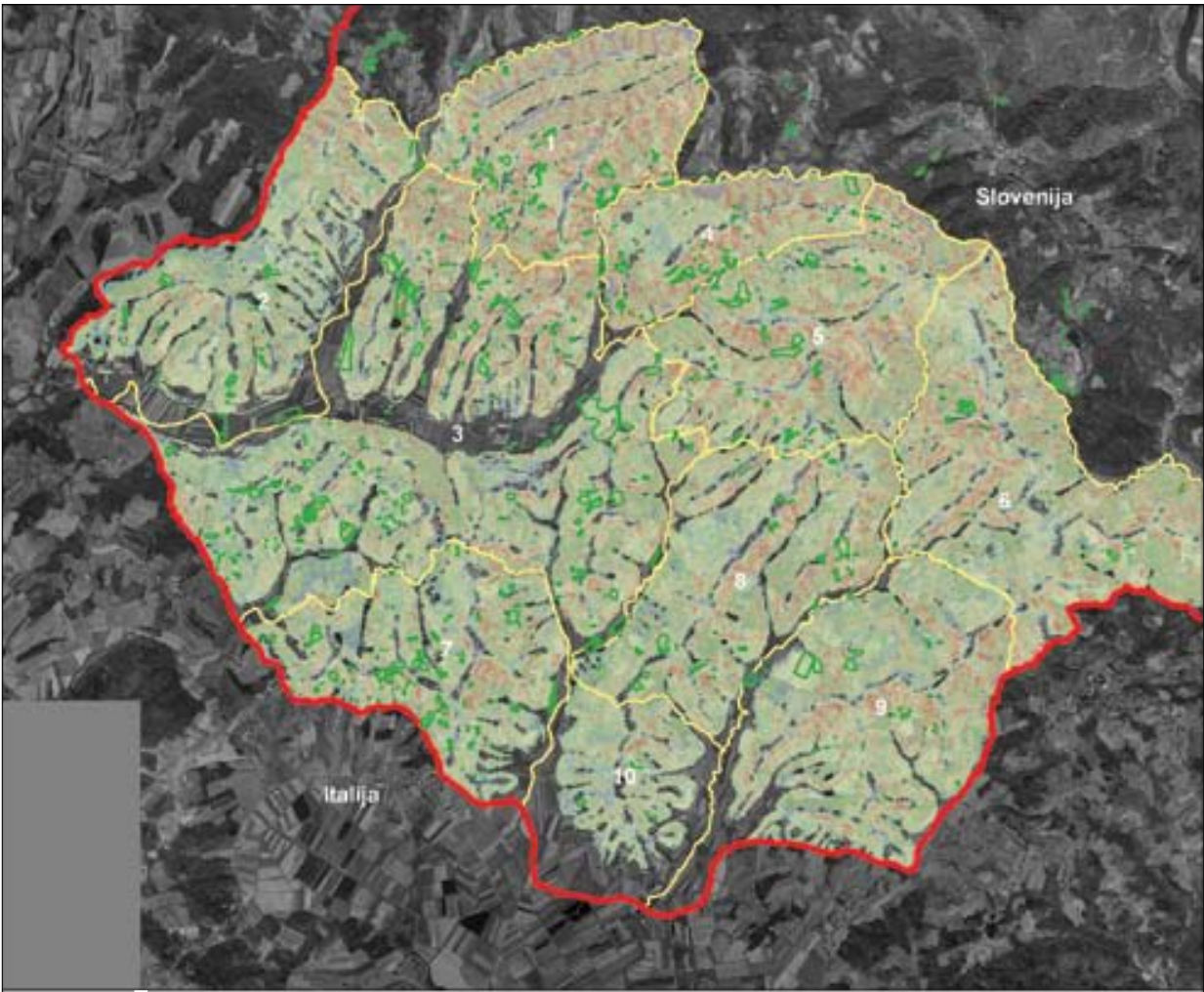

\section{Legenda:}

Kategorija plazovitosti

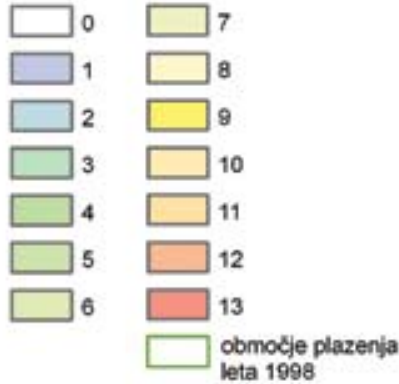

Katastrska obcina

1 Višnjevik

2 Neblo

3 Biljana

4 Vedrijan

5 Ŝmartno

6 Kojsko

7 Medana

8 Kozana

9 Cerovo

10 Vipolze

\section{Upravna razdelitev}

meja katastrske obcine

drzavna meja 
Slika 3: Zemljevid plazovitosti, izdelan s probabilistično metodo.

Figure 3: Probability landslide hazard map.

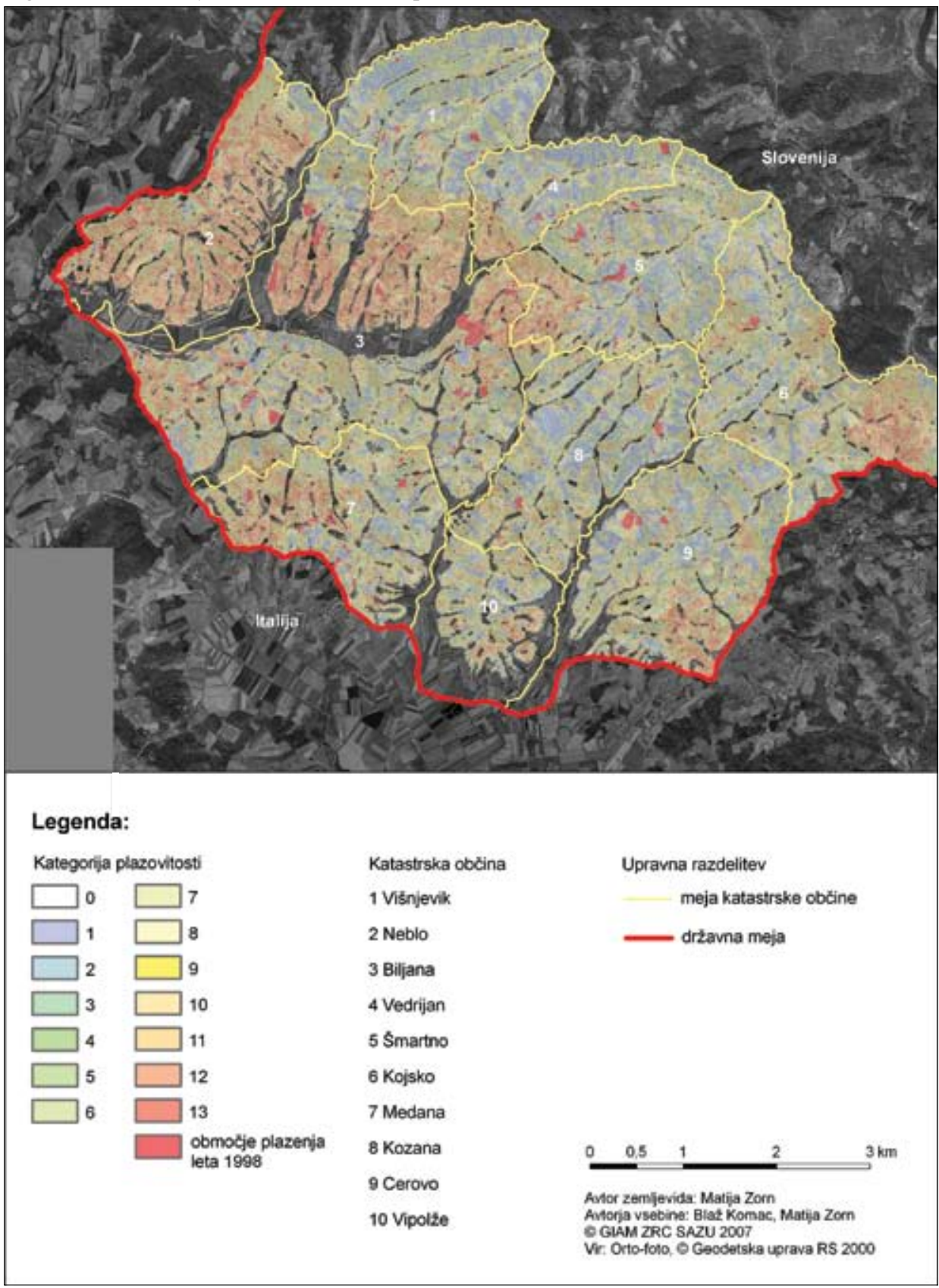


Slika 4: Zemljevid plazovitosti katastrske občine Medana, izdelan z deterministično metodo.

Figure 4: Deterministic landslide hazard map of the Medana cadastral community.

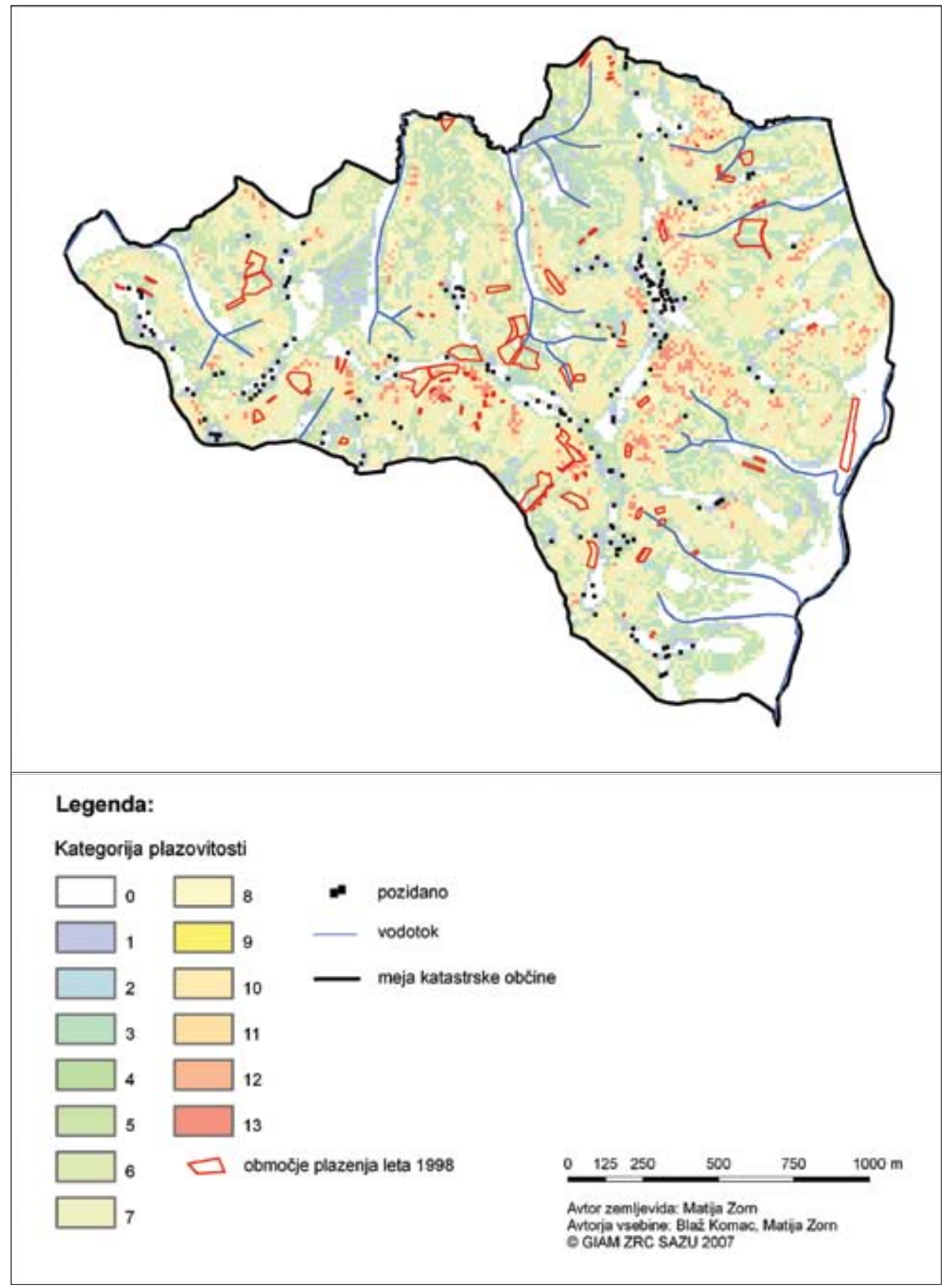


Probabilistični zemljevid kaže dosti večjo regionalno raznolikost. Plazovitost je največja v zahodnem delu gričevja, najmanjša pa v severovzhodnem. Enake kategorije plazovitosti na tem zemljevidu pokrivajo večje sklenjene površine.

Zemljevid je bližje stanju v naravi, saj kot plazovita niso prikazana samo strma, ampak tudi skladna pobočja. Prav slednja pa so najbolj podvržena plazenju. Večjo pogostnost zemeljskih plazov na skladnih pobočjih v osrednjem in zahodnem delu obravnavanega območja sta potrdila tudi ogled terena in pogovor s kmetovalci.

Sodeč po determinističnem zemljevidu plazovitosti v katastrski občini Medana naj bi bila največja možnost nastanka zemeljskih plazov v južnem, vzhodnem in severovzhodnem delu. Najbolj naj bi bila plazovita območja tik pod slemeni, kjer je velik naklon. Ogled terena je pokazal, da na tem območju zemeljskih plazov praktično ni. Flišna pobočja so tam res strma, vendar so neskladna, imajo plitvejšo preperino in so bolj stabilna.

Na probabilističnem zemljevidu plazovitosti v katastrski občini Medana je kot najbolj plazovit prikazan zahodni del obravnavanega območja. S terenskim ogledom smo ugotovili, da ta zemljevid bolje odraža razmere v naravi kot deterministični. V vzhodnem delu in severnem delu je nastala večina zemeljskih plazov leta 1998, prav tako zemeljski plazovi, ki jih je ugotovil Grimšičar (1962).

Razlike med zemljevidoma prikazujeta tudi naslednji sliki. Prikazano je povirje enega od potokov v Goriških brdih. Po determinističnem zemljevidu je plazovitost največja zlasti na območjih z velikimi nakloni. Probabilistični zemljevid pa prikazuje kot plazovita območja tudi bregove potoka in pobočja, ki so usmerjena proti jugu. Na njem so bolj plazovita območja tudi bolj sklenjena, kot na determinističnem zemljevidu. Iz prikaza so prav tako kot na prejšnjih slikah izvzeta območja z naklonom pod $6^{\circ}$.

\subsection{Plazovitost in razvoj reliefa}

Ugotovili smo, da je poglavitni vzrok za večjo plazovitost v zahodnem delu skladnost med usmerjenostjo pobočij in vpadom kamninskih plasti. Na pobočjih z razmeroma majhnim naklonom se zaradi hitrega preperevanja fliša povečuje debelina preperine. Ko njena debelina preseže kritično vrednost oziroma maso, ta pa je odvisna tudi od vsebnosti vode, gmota splazi v nižjo lego. Plitvi zemeljski plazovi najpogosteje nastajajo na terasiranih pobočjih nekaj deset metrov pod slemeni. Globoki in večji zemeljski plazovi so najpogostejši na spodnjem delu pobočij in nastajajo zaradi njihovega spodkopavanja $\mathrm{z}$ bočno erozijo potokov.

Zaradi opisanega procesa je preperina najdebelejša na slemenih. Na pobočjih, kjer prevladujejo denudacijsko-erozijski procesi, je njena debelina manjša. Odvisna je od skladnosti in naklona pobočja. Tako se je skoraj polovica zemeljskih plazov sprožila pri naklonih $12-20^{\circ}$, četrtina pri naklonih $6-12^{\circ}$ in šestina pri naklonih $20-32^{\circ}$. Na plazenje vpliva tudi pogostnost plazenja; daljši čas kot je pretekel od zadnjega plazenja, večja je možnost za nov pojav. Nedvoumen pa je tudi vpliv vsebnosti vode v preperini na plazenje. Plazovino namakajo zlasti tokovi vode v preperini, zelo pogosti so tudi vodni tokovi na stiku preperine in flišnih kamnin. Zato lahko kamnina tudi pod preperino prepereva mnogo hitreje, kot bi sicer. Razumljivo je, da zaradi tega na plazenje močno vplivajo izdelava teras, oranje, zlasti pa rigolanje, pri katerem se premešajo horizonti prsti, seže pa celo do matične kamnine. 
Slika 5: Zemljevid plazovitosti katastrske občine Medana, izdelan s probabilistično metodo.

Figure 5: Probability landslide hazard map of the Medana cadastral community.

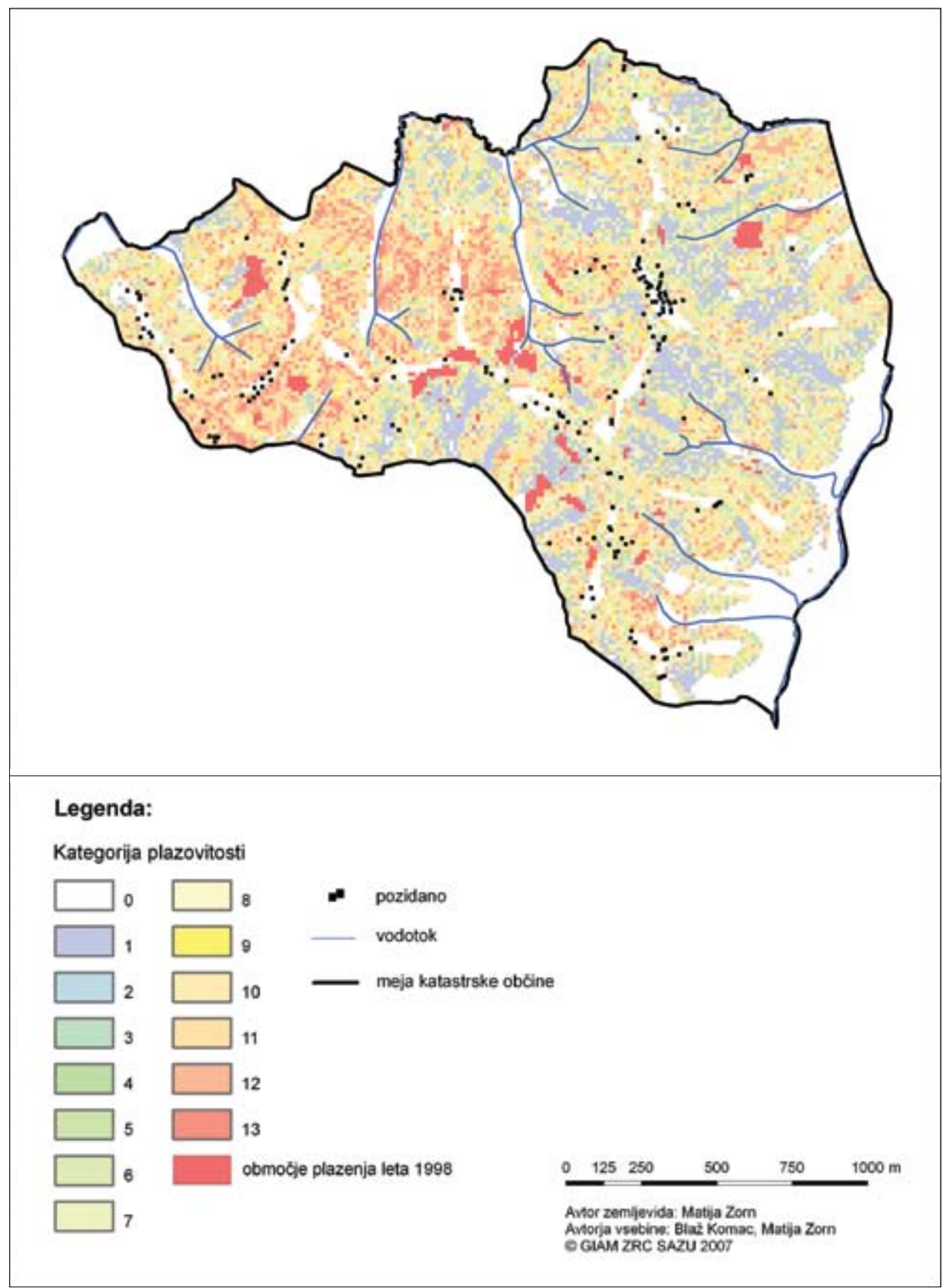


Slika 6: Izsek iz determinističnega zemljevida plazovitosti.

Figure 6: Section of the deterministic landslide hazard map of the Medana cadastral community.

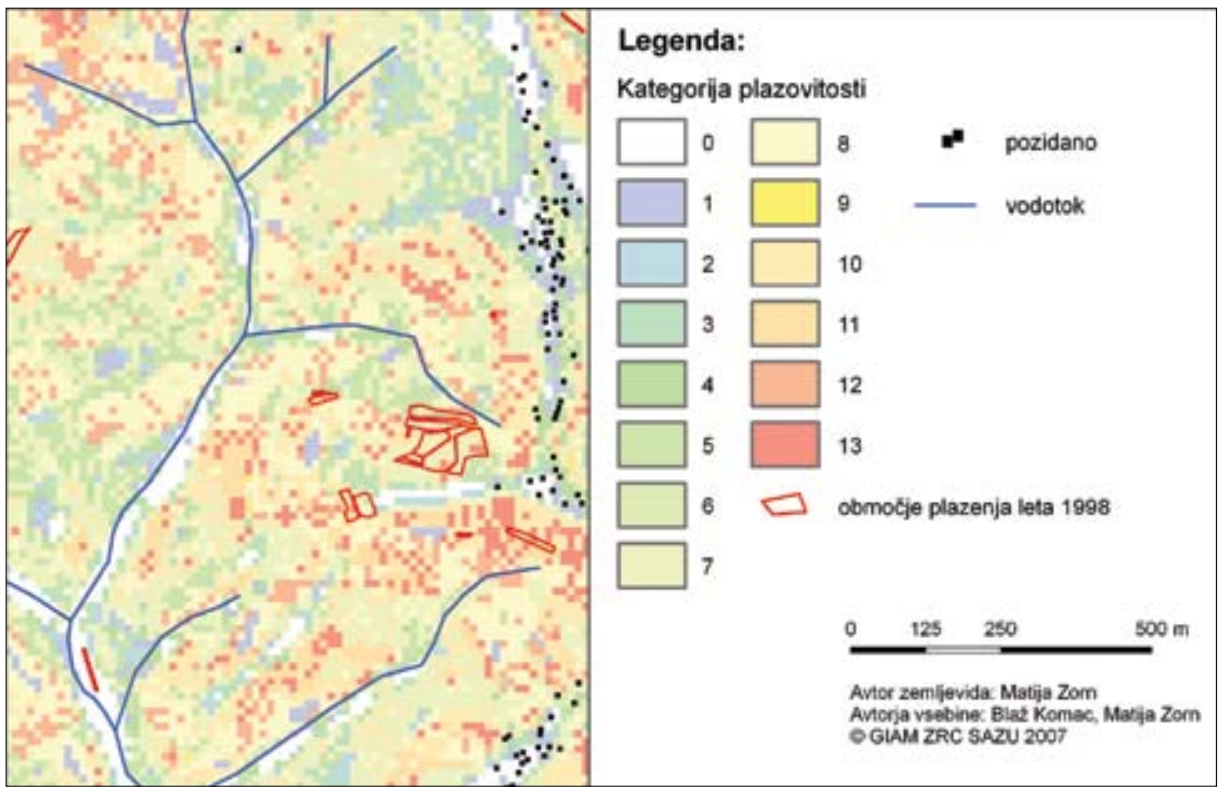

Slika 7: Izsek iz probabilističnega zemljevida plazovitosti.

Figure 7: Section of the probability landslide hazard map of the Medana cadastral community.

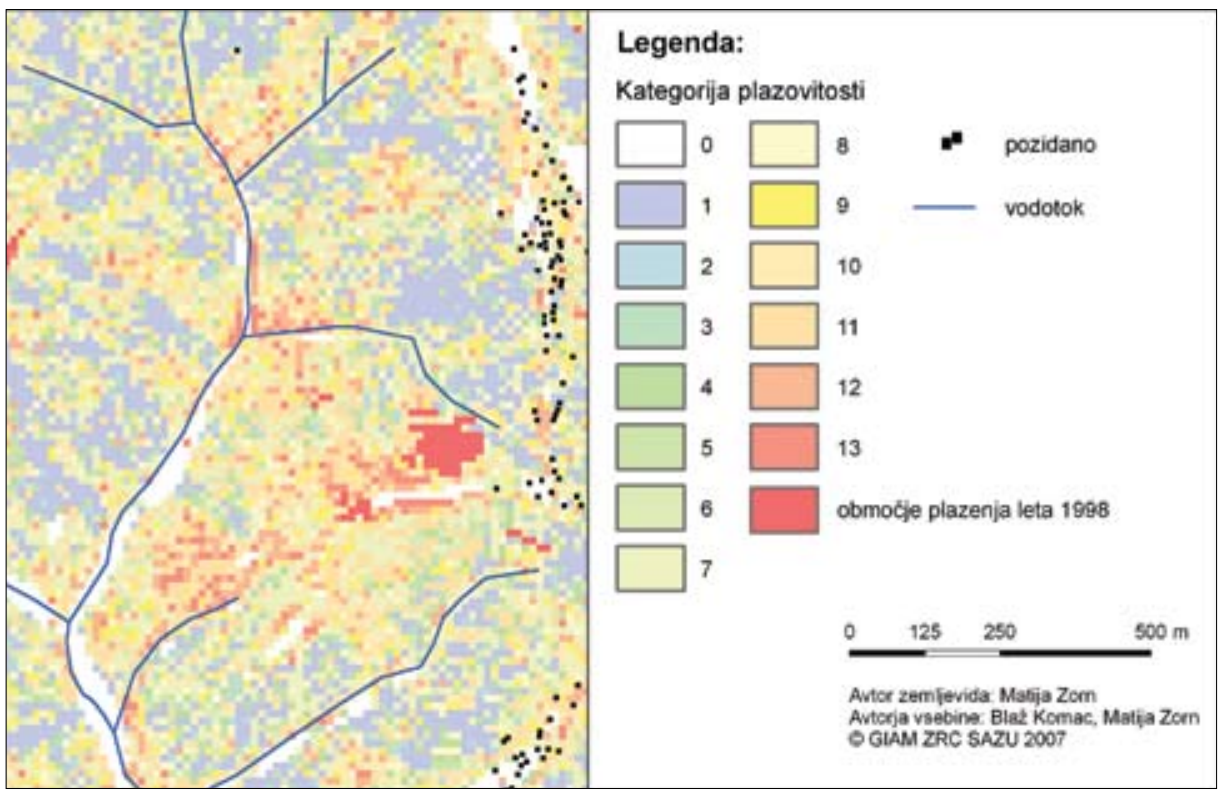


Največji delež (40 \%) zemeljskih plazov je nastal tik pod zgornjimi konveksnimi deli pobočij v oddaljenosti približno $70 \mathrm{~m}$ od slemen. $Z$ zemeljskimi plazovi v povirjih nastajajo značilna konveksno-konkavna pobočja. Končni rezultat preoblikovanja reliefa pa so:

- ploska, uravnana slemena z razmeroma debelo preperino $(4 \mathrm{~m})$,

- strmi osrednji deli pobočij s plitvo preperino $(<2 \mathrm{~m})$, na katerih prevladujejo erozijskodenudacijski procesi in nastajajo zemeljski plazovi,

- položna in konkavna pobočja na stiku z dolinskim dnom; ali pa jih od ravnine loči oster pregib, ki je posledica bočne erozije.

Tako smo s pomočjo probabilističnega zemljevida plazovitosti in terenskega dela ugotovili, da so (manjši) usadi in (večji) zemeljski plazovi pomemben dejavnik pri preoblikovanju reliefa $v$ povirnih delih dolin $v$ flišni pokrajini Goriških brd. Tega ne bi mogli ugotoviti zgolj $\mathrm{z}$ uporabo determinističnega zemljevida plazovitosti.

\section{UPORABA ZEMLJEVIDA PLAZOVITOSTI ZA UGOTAVLJANJE OGROŽENOSTI VINOGRADNIŠKIH TERAS, CESTNEGA OMREŽJA IN STAVB}

Za življenje velikega števila ljudi v Goriških brdih so pomembne vinogradniške terase. Zato smo ugotavljali povezanost terasiranih območij (Berčič 2007) in kategorij plazovitosti.

S probabilistično metodo smo ugotovili, da kar polovica teras z njihovo okolico leži na nadpovprečno plazovitih območjih. Petina jih leži na območjih s povprečno plazovitostjo, nekaj manj kot tretjina pa na območjih s podpovprečno plazovitostjo. Po izračunu z manj ustrezno deterministično metodo ležijo terase približno enakovredno na območjih s podpovprečno, povprečno in nadpovprečno plazovitostjo.

Sliki 8 in 9 prikazujeta razmerje med plazovitostjo in oddaljenostjo določenega območja od teras. Če smo z že omenjenim dodatnim terenskim delom ugotovili, da je probabilistični zemljevid plazovitosti primernejši od determinističnega, lahko na podlagi primerjave probabilističnega zemljevida plazovitosti in zemljevida vinogradniških teras to potrdimo. Po determinističnem zemljevidu naj bi bilo več plazovitih terasiranih območij v večji oddaljenosti od teras (nad $100 \mathrm{~m}$ ), medtem ko naj bi bilo sodeč po probabilističnem zemljevidu večje površine plazovitih terasiranih območij v manjši oddaljenosti od teras (pod $100 \mathrm{~m}$ ) - to pa je bolj pričakovano.

Sklenemo, da so vzrok za plazenje na gričevnatih vinogradniških območjih tudi vinogradniške terase. Zaradi premeščanja preperine je kritičen zlasti čas njihove gradnje. Takrat lahko voda doseže flišno podlago. Kasneje pa je pomembno, kako je izdelano odvodnjavanje (Ažman Momirski in Berčič 2007). Poznamo že primere, ko je slabo narejeno odvodnjavanje teras povzročilo močno erozijo (Valenčič 1970, 145).

Gradnja vinogradniških teras je kljub plazenju možna, saj dobiček od prodaje kmetijskih proizvodov omogoča povrnitev stroškov za porabljeni čas (tudi do nekaj tednov letno) in delo, ki ga imajo vinogradniki z vzdrževanjem teras. Zemeljski plazovi so povečini vezani 
na intenzivne padavine, ki so (z vidika človeka) razmeroma redek pojav. Poleg tega je manjše zemeljske plazove, ki nastanejo na pobočjih v (do) nekaj metrov debeli preperini, pogosto mogoče sanirati le $\mathrm{z}$ ureditvijo odvodnjavanja.

Slika 8: Plazovitost površja voddaljenosti pod $100 \mathrm{~m}$ od teras.

Figure 8: Landslide hazard in the distance from terraces, lower than $100 \mathrm{~m}$.

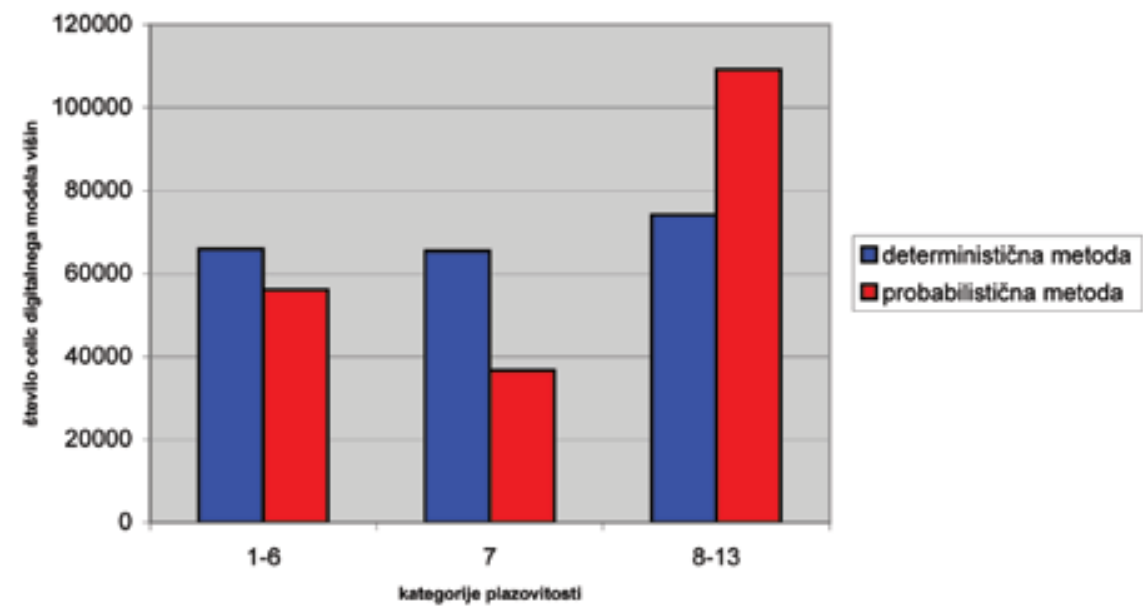

Slika 9: Plazovitost površja v oddaljenosti nad 100 m od teras.

Figure 9: Landslide hazard in the distance from terraces, higher than $100 \mathrm{~m}$.

število celic digitalnega modela višin

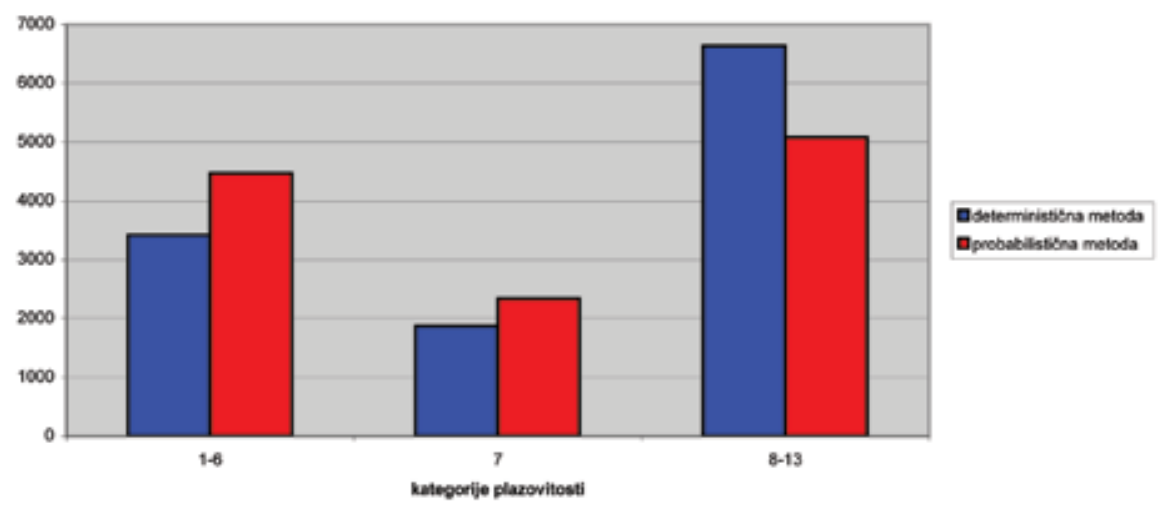


Z družbenogospodarskega vidika, zlasti z vidika dostopnosti stavb, naselij in proizvodnih obratov ter kmetijskih območij je zelo pomembna ogroženost cestnega omrežja zaradi plazovitosti. Preučili smo povezanost kategorij plazovitosti in cestnega omrežja v južnem delu Goriških brd (Berčič 2005). Ceste smo po pomenu razdelili v tri razrede: glavne prometnice, krajevne prometnice, kmetijske poti. S pomočjo modeliranja smo ugotovili, da je zaradi zemeljskih plazov ogrožena tretjina glavnih cest, kar desetina $(9,8 \mathrm{~km})$ pa jih poteka po območjih najvišje plazovitosti. Neogroženih je $56,6 \mathrm{~km}$ glavnih cest. Zemeljski plazovi močno ogrožajo približno četrtino $(24,1 \mathrm{~km})$ krajevnih prometnic, več kot polovice $(54 \mathrm{~km})$ krajevnih prometnic pa zemeljski plazovi ne ogrožajo neposredno. Po plazovitih območjih sta speljani več kot dve tretjini od 629,48 km kmetijskih poti. Četrtina jih leži na območjih $\mathrm{z}$ visoko ogroženostjo zaradi plazenja. Približno četrtine kmetijskih poti zemeljski plazovi ne ogrožajo.

Z vidika urejanja prostora, ki je pri nas v pristojnosti občin, je zanimiva primerjava območij plazovitosti z območji poselitve (Ehiš 2002). Na celotnem območju južnih Goriških brd je poseljenih približno 50 ha površin. Približno tretjina stavb v južnih Goriških brdih leži na plazovitih območjih. Od tega jih polovica leži na območjih z veliko možnostjo nastanka zemeljskih plazov. Zemeljski plazovi malo ali nič ne ogrožajo četrtine stavb.

\section{SKLEP}

Goriška brda so ena od slovenskih pokrajin, kjer naravne razmere omogočajo intenzivno kmetijsko proizvodnjo, številni dejavniki pa človekovo dejavnost onemogočajo. Zemeljski plazovi so v Goriških brdih stalen problem (Grimšičar 1962; Vrišer 1954; 1956).

S primerjavo determinističnega in probabilističnega zemljevida plazovitosti Goriških brd smo ugotovili, da je probabilistična metoda ustreznejša, rezultati pa bolje odražajo naravne razmere.

Zemljevid je uporaben za načrtovanje rabe prostora do ravni naselja in je dobra podlaga za detajlno geomorfološko kartiranje plazovitih območij. $Z$ vidika kmetijskega gospodarjenja je do neke mere zaskrbljujoča ugotovitev, da je plazovit pretežni del $(80 \%)$ preučevanega območja oziroma južnih Goriških brd. Zato bi bilo treba z vidika plazovitosti zlasti kmetijsko dejavnost, ki z gradnjo vinogradniških teras povzroča nestabilnost pobočij in s tem povezane stroške sanacije (čas in denarna sredstva), dolgoročno usmeriti na območja z manjšo plazovitostjo, ki se povečini raztezajo v vzhodnem delu južnih Goriških brd. Pri gradnji teras je treba upoštevati pogostnost zemeljskih plazov pri določenih naklonih, zelo pomemben dejavnik pa je vpad kamninskih plasti ali njihova usmerjenost glede na potek pobočja.

Na plazovitost bi morali biti posebej pozorni tudi pri gradnji novih prometnic in stavb oziroma pri določanju poselitvenih območij ali širjenju naselij, ki pa zaradi dolgotrajne poseljenosti območja v veliki meri že upoštevajo naravne razmere. 


\section{Zahvala}

Raziskavo smo izdelali v okviru mednarodnega projekta Alpter, ki je del programa EZ INTERREG IIIB Alpski prostor (EU INTERREG IIIB Alpine Space). V projektu smo sodelovali pod okriljem Fakultete za arhitekturo Univerze v Ljubljani in vodstvom dr. Lucije Ažman Momirski.

\section{Literatura}

Ažman Momirski, L., Berčič, T. 2007: Priporočila za izdelavo teras: primer obnove vinograda v Goriških brdih. Fakulteta za arhitekturo Univerze v Ljubljani. Ljubljana.

Berčič, T. 2005: Zemljevid prometnic v Goriških brdih. Digitalna podatkovna baza. Fakulteta za arhitekturo. Ljubljana.

Berčič, T. 2007: Zemljevid vinogradniških teras in cest v Goriških brdih. Digitalna podatkovna baza. Fakulteta za arhitekturo. Ljubljana.

Dempster, A. P. 1968: A generalization of Bayesian inference. Journal of the Royal Statistical Society B30, str. 205-247. Medmrežje: http:/www.glennshafer.com/assets/downloads/ articles/article48.pdf (13. 7. 2006).

Enotna evidenca hišnih številk. 2002.Geodetska uprava Republike Slovenije. Ljubljana.

Grimšičar, A. 1962: Inženirsko-geološke razmere v Goriškišh brdih. Geološke razmere v Goriških brdih. Geološki inštitut Slovenske akademija znanosti in umetnosti. Ljubljana.

Komac, B., Zorn, M. 2006: Zemeljski plazovi v Goriških brdih. Primorske novice 60-185 (11. avgust 2006), str. 20. Koper.

Perko, D. 1992: Ogroženost Slovenije zaradi naravnih nesreč. Ujma 6, str. 74-77. Ljubljana.

Shafer, G. 1990: Perspectives on the theory and practice of belief functions. International Journal of Approximate Reasoning 3, str. 1-40. Internet: http:/www.glennshafer.com/ assets/downloads/articles/article48.pdf (13. 7. 2006).

Valenčič, V. 1970: Vrste zemljišč. Gospodarska in družbena zgodovina Slovencev: Zgodovina agrarnih panog 1, str. 131-146. DZS. Ljubljana.

Vrišer, I. 1954: Goriška brda. Geografski zbornik 2, str. 51-113. Ljubljana.

Vrišer, I. 1956: Morfološki razvoj v Goriških brdih. Geografski zbornik 4, str. 159-183. Ljubljana.

van Westen, C. J. 1994: GIS in landslide hazard zonation: a review, with examples from the Andes of Colombia. Mountain Environments and Geographic Information Systems, str. 135-185. Taylor and Francis. London.

Zorn, M., Komac, B. 2002: Pobočni procesi in drobirski tok v Logu pod Mangartom. Geografski vestnik 74-1, str. 9-23. Ljubljana.

Zorn, M., Komac, B. 2004: Deterministično modeliranje ogroženosti zaradi zemeljskih plazov in skalnih podorov. Acta geographica Slovenica 44-2. Ljubljana.

Zorn, M., Komac, B. 2005: Geografska analiza naravnih nesreč v domači pokrajini - primer zemeljskih plazov. Geografija v šoli 15-3, str. 52-60. Ljubljana. 


\section{MODELLING OF NATURAL PROCESSES ON THE EXAMPLE OF LANDSLIDES}

\section{Summary}

In the article, the probabilistic landslide hazard map for the Goriška Brda hills and a deterministic landslide hazard map for the same area are compared.

Among the preconditions that influence landsliding, we considered eight factors in the model used to calculate the landslide hazard: lithological composition, surface inclination, horizontal curvature of the surface, dip of strata, a stream power index, an index of soil saturation, maximum 24-hour precipitation, and land use. The data on 800 landslides that occurred in 1998 was used for the probabilistic map elaboration.

The probabilistic map was elaborated using the Dempster-Shafer algorithm, comparing the significance of individual landslide factors based on field work data. The algorithm compares the factors in every hierarchically possible way and calculates the values in landslide hazard areas for each factor considered. Areas ultimately defined as landslide hazard areas are those that relative to the highest possible number of considered parameters most resemble areas where landslides have already occurred so the quality of the data entered on actual landslides is very important.

The deterministic method was based on weighting influential factors. Due to the different scales used to measure individual factors, it is necessary to standardize the individual influential factors. In this way, we can compare different maps. Defining weights is subjective since we must judge how much weight to give an individual factor, particularly where it is difficult to rely on the literature. Using standardization and weighting, we elaborate partial maps. With the combining of partial maps we acquire an index which expresses the possibility of triggering landslides.

The results are two geomorphic process maps that show landslide source areas.

The advantage of the weighting method is the simplicity and short duration of the procedure. Its weaknesses are methodological since the weighting process is subjective. The advantages of the probabilistic method are its reliability, independency on our predispositions, while its disadvantage is a complex process of long duration.

The maps were finally compared and verified by field work. It was established that the results of the probabilistic model are closer to situation in nature than the results of the deterministic one. An accurate understanding of the natural processes enables the identification of threatened areas in the landscape and the direction of settlement and human activities, especially farming and building of vineyard terraces, to safer areas. 